legal relations, etc., are revealed. Attention is paid to the varieties of such status, in particular, the constitutional and legal status of the subjects of state and legal regulation of the sphere of physical culture and sports.

The subjects of the sphere of physical culture and sports in Ukraine are quite broad category, the legislator to them includes: physical persons engaged in physical culture and sports, including sportsmen; specialists in the field of physical culture and sports; establishments of physical culture and sports; relevant authorities. In fact, only the latter are subjects of state regulation of the field of sports and sports. In view of the functional criterion, the following are distinguished: the President of Ukraine, the Verkhovna Rada of Ukraine, the Cabinet of Ministers of Ukraine, the central body of executive power implementing state policy in the field of physical culture and sports.

The circle of subjects of state regulation of the sphere of physical culture and sports is narrower than the circle of subjects of regulation of the sphere. For example, the second group of entities is local government in Ukraine. The main subject of state-legal regulation of the sphere of physical culture and sports, of course, is the state, but its constitutional-legal status needs to be clarified.

The legal status of the subjects of state-legal regulation of the sphere of physical culture and sports is a complex, multidimensional and integration category of systemic character, which objectively reflects the positive and negative features of the political-legal system of the state. This is a legally-mandated position or provision of a specially authorized entity, which is expressed in the existing set of powers, duties; responsibility, reflects the regulated relationship with other participants in the public relations of the respective spheres of life.

On the basis of the study of constituent elements, as well as the results of its implementation, certain problems in this field were identified, directions and ways of improvement of such status, corresponding normative legal bases and practice of implementation were outlined.

Keywords: physical culture, sport, sport relations, state, legal regulation, legislation, state authorities.

DOI: $10.33766 / 2524-0323.89 .33-44$

УДК 342.729:340.113

\author{
М. А. Самбор, \\ кандидат юридичних наук, \\ начальник сектора моніторингу \\ Прилуцького відділу поліції \\ Головного управління Національної поліції \\ в Чернігівській області \\ (м. Чернігів - м. Прилуки, Україна) \\ e-mail: NIKOLAS783@ukr.net \\ iDhttps:/ / orcid.org/ 0000-0002-0446-3892
}

\title{
ОСОБЛИВОСТІ ЮРИДИЧНОЇ ТЕРМІНОЛОГІЇ У ФОРМУЛЮВАННІ ПОНЯТТЯ ПРАВА НА СВОБОДУ МИРНИХ ЗІБРАНЬ
}

У статті досліджуються особливості використання юридичної термінології, покликаної формулювати в змісті нормативно-правових актів національного законодавства України поняття права на свободу мирних зібрань. Аналіз національного законодавства України дозволив зробити висновок про те, що для позначення права на свободу мирних зібрань законодавець використовує різні конструкції, а саме «право на свободу мирних

(C) Самбор М. А., 2020 
зібрань», «право на мирні зібрання», «право збиратися мирно». Така юридична технологія у використанні юридичної техніки на позначення права людини не гарантує єдності його розуміння та змісту, який містить у собі вказаний юридичний термін. 3 урахуванням викладеного пропонується внести зміни до чинного законодавства України та використовувати єдине поняття, яке найбілы повно, зрозуміло та доступно розкриє зміст, мету та механізм (алгоритм) його здійснення даного права - «право на свободу мирних зібрань».

Ключові слова: право на свободу мирних зібрань, право збиратися мирно, право на мирні зібрання, юридична техніка, юридична термінологія.

Постановка проблеми. Україна XXI ст. являє собою молоду країну, котра ставить перед собою амбітні цілі розбудови демократії та верховенства права, захисту та охорони прав і свобод людини. Формування власної правової системи та системи законодавства натикається на безліч рифів, котрі обумовлюються наявними течіями в доктринах розвитку права і законодавства в державі. Сьогодні в країні борються представники двох основних спрямувань: «старої» радянської правової школи та ті, які категорично відкидають історико-правову школу, що була джерелом формування українського законодавства, та відстоюють однозначний позитивний ефект рецепщії західної традищії правового регулювання суспільних відносин.

Як результат, власна мудрість українського народу втрачається, що розбалансовує системи права і законодавства, створюючи суперечності у формулюванні правових приписів, неоднозначність застосування норм у регулюванні однотипних суспільних відносин, а також позбавляючи правову дійсність визначеності, зрозумілості та однозначності в правозастосуванні.

Особливо гостро та актуально вказані питання постають, коли невизначеність та неоднозначність у використанні притаманні правам, свободам та інтересам людини і громадянина.

Аналіз останніх досліджень і публікацій. Актуальні питання юридичної термінології були предметом не одного наукового пошуку. Юридична термінологія, як предмет наукового пізнання, була предметом науково-практичних конференщій, які об'єднали вітчизняних та зарубіжних науковців. Серед дослідників юридичної термінології та їх проблемних аспектів слід виділити Л. М. Демидову, Л. А. Луць, М. І. Панова, П. М. Рабіновича, І. Д. Шутака та інших.

Останнім часом дослідження юридичної термінології характеризуються своєю різноплановістю, що є наслідком багатогранності предмета наукових пошуків. Зокрема, О. М. Каленюк присвятила своє дослідження історико-правовим витокам української правничої термінології на західноукраїнських землях [14]. Визнання української мови, створення умов для їі функціонування було чи не найважливішим чинником українського національного відродження, а, отже, й українського нащіонального державотворення [14, с. 42]. Аналіз праці О. М. Каленюкдозволив зробити висновок про те, що українська юридична термінологія є результатом перш за все розвитку української мови, охоплення нею всіх сфер суспільного життя, зокрема їі правової складової. 
Т. С. Подорожна вказала, що вимоги до формальної визначеності права і його системності зростають при переході від традиційного суспільства до раціоналістичного. Надалі вони підвищуються у зв' язку з раціоналізацією щоразу більшого кола суспільних відносин, що, своєю чергою, посилює значення законодавчої (правотворчої) техніки та термінології (останнє додано нами - М. С.), а отже, вимагає уникнення пов'язаних із нею помилок [16, с. 53]. У такий спосіб підвищується роль юридичної термінології, яка гарантує усунення можливих розбіжностей розуміння та застосування норм права, а також формулюе правотворчі та законотворчі технології, спрямовані на продукування якісних та зрозумілих правових норм, здатних ефективно регулювати суспільні відносини.

Очевидно, що юридична термінологія є складовою правової технології. С. В. Бахвалов визначає законодавчі технології, як здійснювана в конкретно-історичних умовах та в установленому порядку законотворча діяльність компетентного суб'єкта по формуванню стійкої системи законодавства за допомогою науково обгрунтованого комплексу правотворчих дій, принципів, засобів, прийомів та правил [15, с. 8], на наш погляд, можуть якісно реалізуватися виключно за умов єдності використання термінології, яка пов'язує елементи правової системи, формулюючи принцип ії єдності, послідовності, зрозумілості й доступності.

I. М. Кочан досліджує юридичну термінологію крізь призму лінгвістики [17], Н. П. Яцишин вивчала юридичну термінологію як об'єкт мовознавчих досліджень [18]. Незважаючи на наявні розвідки у вказаному напрямку, ряд питань використання юридичної термінології залишаються малодослідженими. Одним із таких питань $є$ використання юридичної техніки у формулюванні та викладі норм, що визначають зміст права на свободу мирних зібрань та механізм (алгоритм) здійснення цього права.

Проблема багатозначності юридичної термінології, що істотно впливає на застосування юридичної техніки в процесі правотворення. Вона виражає не тільки плюралізм наукових підходів, але й реальну складність і неоднозначність самої соціально-правової дійсності [6, с. 43]. Як наслідок, розуміння, а звідси й застосування права на свободу мирних зібрань у рівній мірі, якщо не більше, зазнає невиправних та необгрунтованих обмежень та заборон. Це стосується і захисту цього права із використанням всіх правових засобів.

Формулювання цілей. Враховуючи викладене, метою статті обрано дослідження в національному законодавстві України юридичної техніки, покликаної формулювати зміст права на свободу мирних зібрань.

Виклад основного матеріалу. Суттєвим елементом юридичної техніки є юридична термінологія - мовне відображення державно-правових явищ [7, с. 106]. Мова законодавчих та правозастосовних актів повинна максимально бути зрозумілою пересічному громадянину, тобто бути літературною. Саме юридичні терміни дають можливість досягти чіткості та ємності правового акта, лише за їх допомогою можна виключити двозначність. Отже, чистота, культура мовлення на лексичному рівні має бути досягнута посиленою увагою до кожного слова, терміна, термінологічного словосполучення [7, с. 106].

Філософський зміст поняття точності являе собою суворе, ретельне дотримання необхідних норм, вимог установлених показників [1, с. 219], що на наш погляд, можливе в умовах однозначності використання юридичної термінології, 
оскільки їі розмитість, неоднозначність використання термінів та понять на позначення одних і тих самим правових явищ не сприяє розумінню їх змісту, i, головне, ефективному здійсненню.

Юриспруденція, будучи досить герменевтичною наукою, відрізняться від інших наукових напрямів явно вираженим тяжінням до точності формулювань і дефініцій. I така традищія зберігається ще з часів римського права - колиски юриспруденції у іï сучасному розумінні. І це не просто філологічні експерименти задля виявлення найбілыш вправного майстра словесної еквілібристики, а сувора вимога юридичної практики, виробленої впродовж тисячоліть і сторіч розвитку законотворення, адже від точності й довершеності формулювань може залежати не тільки доля окремої взятої людини, відносно якої відбувається правозастосування, а й подекуди доля цілих народів і континентів, коли, приміром, ідеться про епохальні міжнародні договори чи прийняття основного закону для держави, що визначатиме подальший їі шлях розвитку [2, с. 14].

Без перебільшення, для світового правопорядку такі фундаментальні міжнародні договори, як Загальна декларація прав людини, Конвенція про захист прав людини й основоположних свобод, інші міжнародні та регіональні документи у сфері прав людини, стали міждержавним, світовим надбанням історико-правової науки і практики, які у своєму змісті зосередили уявлення людства про права людини, зокрема й право на свободу мирних зібрань, сформулювавши його саме в такій правовій конструкції як «право на свободу мирних зібрань». Отже, міжнародне та європейське співтовариства однозначно висловилися щодо визначення юридичного терміна у відповідному словосполученні.

Європейський підхід до удосконалення законодавства характерний прагненням до мінімалізащії радикальних змін, до доповнення і уточнення раніше прийнятих законів, прагненням постійно еволюційно поліпшувати чинні закони, а не повністю замінювати їх новими. Такий підхід дозволяє сполучати прогресивні зміни із забезпеченням відносної стабільності законодавства, його «впізнавання», він має синтезуючий характер [3, с. 4]. За понад 60-річну історію розвитку правовідносин, теоретична конструкція терміна «право на свободу мирних зібрань» у міжнародному праві не зазнала змін, що засвідчує ефективність обраних на позначення даного правового явища понять, які увібрали в себе повноту змісту, зрозумілість та доступність.

Спеціальні юридичні терміни передають основний смисл нормативного тексту i, займаючи відносно невеликий обсяг, складають основний і найбілыш інформативний пласт законодавства, сприяють найбільш ефективному й оптимальному викладу нормативних розпоряджень [9, с. 41]. Невдалі формулювання або неточні вживання термінів, допущення суперечностей, некоректні посилання і т. ін. породжують зволікання, сприяють помилкам, виникненню непорозумінь у практичній правничій діяльності, заважають ефективному реформуванню багатьох сфер державного та громадського життя. Отже, сьогодні вже не викликає сумнівів той факт, що юридична техніка має не лише прикладне (допоміжне), але й істотне значення для регулювання суспільного життя [4, с. 53]. Слід зауважити, що семантична цілісність термінологічних сполучень зумовлена не тільки їх розкладністю, а й синтаксичним зв' язком [12, с. 152]. На наш погляд, саме формулювання з використанням зазначених термінів, а саме: «право», «свобода», «мирний» та «зібрання», 
- підкреслює існування в кожного суб'єкта правовідносин певної можливості, яка обумовлена з одного боку природою людини та утворених нею об'єднань безперешкодно, незалежно від позиціювання стосовно даної можливості з боку будь-яких інститутів суспільства, перш за все держави та їі органів чи посадових осіб, здійснити проголошену можливість. Ключовою стала й нормативно-правова фіксація визначальної ознаки соціального блага, на здобуття якого спрямована дана можливість «мирність». Завершальним у цьому словосполученні, спрямованому на позначення даної можливості, є визначення самого блага - «зібрання». Важливим $є$ те, що у всіх нормативно-правових актах для позначення даної можливості має використовуватися ідентичний термін, сформульований словосполученням «право на свободу мирних зібрань».

Упевнені в тому, що ефективне нормативно-правове регулювання відносин щодо здійснення прав, свобод та інтересів людини і громадянина розпочинається саме із якості нормативно-правового матеріалу, який виступає регулятором здійснення правових можливостей. Однією з таких якостей є однозначність використання юридичних термінів, покликаних визначати одні й ті ж правові категорії, явища. Міжнародне право, норми якого регулюють здійснення права на свободу мирних зібрань, цьому підтвердження. Зокрема, ст. 20 Загальної декларації веде мову про право на свободу мирних зборів, ст. 11 Конвенщії про захист прав людини і основоположних свобод - про право на свободу мирних зібрань, а от ст. 21 Міжнародного пакту про громадянські й політичні права використовує поняття «право на мирні збори». Думається, що такий відступ від попередніх термінів зумовлений тим, що в ст. 21 Міжнародного пакту про громадянські й політичні права детально розкривається питання свободи здійснення цього права, а саме те, що користування цим правом не підлягає жодним обмеженням, із зазначенням вичерпного передіку застережень, що відображено у відповідній нормі.

Послідовно перейдемо до української правової системи та використання в змісті нормативно-правових актів термінів, які покликані розкрити зміст права на свободу мирних зібрань та забезпечити умови свободи здійснення даного права. Зокрема, норма ст. 39 Конституції України, на наш погляд, надзвичайно звужено підійшла до формулювання права на совбоду мирних зібрань, оскільки вказаною конституційною нормою проголошено лише право збиратися мирно та без зброї в певних конституційних формах [10, с. 34], здійснення якого гарантується демократичним світом, оскільки в згаданій нормі йдеться виключно про право збиратися мирно та ще й без зброї і проводити лише збори, мітинги, походи й демонстрації. Слід наголосити на тому, що для українських соціальних реалій цілком природнім є мирні зібрання, учасники (перш за все активні) є озброєними, наприклад, щорічні військові паради до Дня Незалежності України. Упевнені в тому, що така форма зібрання, як парад, у своєму змісті має антагоністичну складову, оскільки така ознака, як відсутність зброї у їі учасників, діаметрально протилежна оснащенню учасників парадів, які збираються зі зброєю.

Загальними прийомами та правилами щодо застосування юридичної техніки $є$ дотримання юридичної термінології, тобто системи усталених, загальноприйнятих і визнаних юридичною наукою та практикою юридичних термінів, тобто словесних позначень понять, що використовуються під час викладу змісту закону, іншого нормативно-правового акта чи юридично-значущого документа. Зазначене 
вимагає дотримання вимог термінологічної уніфікації, а саме таких: однозначність - застосування в нормативному акті або іншому юридично значущому документі понять і термінів в одному й тому ж, тотожному значенні; загальна визнаність використання загальновідомих і поширених серед наукової спільноти та пересічних громадян термінів, визначень, формулювань, дефініцій і т.ін., а не надуманих і вигаданих спеціально для певного закону, нормативно-правового акта, юридично значущого документа; стабільність (постійність, усталеність) - закріплення в певній незмінній формі термінології нормативно-правового акта, а не зміна їі з прийняттям кожного нового нормативно-правового акта чи закону; доступність - простота та адекватність термінологіі, що використовується; чіткість у викладі нормативно-правового матеріалу, тобто виключення різного розуміння та можливості багатоманітного тлумачення положень норми права; дотримання певних юридичних конструкцій, тобто непорушних і чітких, відпрацьованих юридичною наукою, законодавчою діяльністю та перевірених практикою правозастосовної діяльності типових схем побудови нормативно-правового матеріалу з використанням особливого типу системного зв'язку між його елементами [4, с. 54-55]. Всупереч такій сформульованій науковій доктрині, суб' єкти законотворення для позначення одних і тих же за своєю суттю і змістом правових понять і категорій користуються різними поняттями, адже вже в нормі, що міститься в ст. 315 Цивільного кодексу України, використовується поняття «право на мирні зібрання», яке, на наше переконання, істотно ширше за те, що гарантується Конституцією України - право збиратися мирно й без зброї. Хоча, вважаємо, що конституційні норми не можуть сфокусувати всі права і свободи людини та громадянина, їх зміст, а лише вказують на певні правові вектори необмеженості відповідних прав, які можуть знаходити свій розвиток як у галузевому законодавстві, так і бути наслідком впровадження в суспільні відносини демократичного принципу верховенства права. Упродовж сказаного зазначимо, що норми Кодексу адміністративного судочинства України (далі - КАС України) у своєму змісті вже використовують саме поняття «право на свободу мирних зібрань» (ст.ст. 46, 280, 281, 371 КАС України). Така правова позищія використання поняття «права на свободу мирних зібрань» у нормах КАС України притаманна обом редакціям згаданого кодексу. Ухвалення вказаних законодавчих актів відбувалося у відповідній хронології: спочатку Конституція України, потому Цивільний кодекс України, і зрештою, Кодекс адміністративного судочинства України. Через те можемо зробити висновок, що поступово суб'єкти законотворення схиляються до науково обгрунтованої доктрини використання на позначення даної правової можливості саме поняття «право на свободу мирних зібрань». Водночас вважаємо, що поступове сприйняття ефективної формули юридичного поняття з позначення права на свободу мирних зібрань має відбиватися не лише в нових нормативно-правових актах, а й шляхом внесення відповідних змін до чинних нормативно-правових актів.

Процес створення норм права має відбуватися у відповідності зі строгими правилами юридичної техніки - системи заснованих на практищі правотворчості правил і прийомів підготовки проектів нормативно-правових актів. За допомогою юридичної техніки забезпечується вичерпне охоплення регульованих питань, до- 
ступність, простота та висока регулятивність правового матеріалу [5, с. 32]. В Основному Законі Держави, який ухвалювався в незалежній Україні, яка наприкінщі XX ст. усіма способами демонструвала прагнення на зближення з Свропейським співтовариством незалежних держав, на наш погляд, доцільно було б вже тоді скористатися міжнародним досвідом, заснованим на принципі верховенства права, у створенні конституційної норми, покликаної відтворити зміст досліджуваного права, а також, спираючись на власний багаторічний правотворчий досвід, використати наступну техніко-юридичну формулу - «право на свободу мирних зібрань», зміст якої підкреслював би і природно-правову доктрину походження, і приналежність цього права кожній особі, свободу його здійснення, перш за все, незалежно від суб'єктів владних повноважень.

Однозначність використання юридичних термінів на позначення одного й того ж правового явища - права на свободу мирних зібрань - впливає не лише на загальне розуміння норм права, а й їх здійснення, оскільки норми ухвалюються саме з метою уніфікації регулювання суспільних відносин.

Однією із важливих проблем, вирішення якої дозволяє забезпечити належну якість нормативно-правових актів, є точність правових норм, що становлять їх зміст. Точність правових норм (i ïх досконалість) виступає обов'язковою умовою якості нормативно-правових актів і, відповідно, належного правового регулювання в суспільстві [8, с. 12-13]. 3 нашої точки зору, використання поняття «право на свободу мирних зібрань» дозволить систематизувати нормативно-правовий матеріал у сфері регулювання цього права, і розбудувати якісну систему правового регулювання суспільних відносин, у яких учасники здійснюють своє право на свободу мирних зібрань, а також створити дієвий механізм захисту та охорони права на свободу мирних зібрань, зокрема їх судовий та позасудовий захист.

Така уніфікація терміна «право на свободу мирних зібрань» у національному законодавстві України сприятиме гармонізащії, яка $є$ м'яким засобом правової інтеграції та здійснюється на принципах рівності, поваги до національного суверенітету, загальновизнаних норм і принципів права, цілеспрямованості, системності, безперервності, врахування національних особливостей та інтересів [11, с. 8]. У такий спосіб Україна продемонструє реальні кроки в правотворчості, спрямовані на інтеграцію нащіонального законодавства до законодавства Євросоюзу, а з іншого - він цілком відповідає національним традиціям правотворчості та законотворчості, оскільки право на свободу мирних зібрань у різних його лексико-граматичних формах відлзеркалювалося в конституційних нормах держави, що існувала на теренах сучасної України впродовж останнього століття [13].

Висновки. Отже, доходимо висновку про те, що юридична термінологія, яка використовуються для позначення права на свободу мирних зібрань, відіграє істотну роль у сприйнятті його змісту суб'єктами здійснення. Упевнені в тому, що пошук ефективних юридичних термінів у юридичній техніці відображає соціальні потреби та історико-правове уявлення суспільства в розумінні даного права, його природи та особливостей здійснення. Якість та однозначність юридичних термінів, що використовуються в нормативно-правових актах, які вживають на позначення права на свободу мирних зібрань, відбиває законодавчу стратегію доступності змісту нормативно-правових актів для суб'єктів, які використовуватимуть зазначені норма- 
тивні приписи для регулювання суспільних відносин, учасниками яких виступатимуть ці суб'єкти. Переконані, що вживання різних юридичних термінів на позначення одного й того ж права на свободу мирних зібрань, віддаляє принщип зрозумілості норм права для суб'єктів його застосування та здійснення, що позначається на ефективності здійснення кожним суб'єктом його права на свободу мирних зібрань. Вважаємо, що для єдності нормативно-правового матеріалу, зрозумілості його нормативних приписів для учасників суспільних відносин, а також ефективного використання учасниками правовідносин їх права на свободу мирних зібрань, доречно привести юридичну термінологію законодавства, яке регулює здійснення права на свободу мирних зібрань, до єдності вживання термінів, які позначать однакові правові явища - право на свободу мирних зібрань, використавши саме таке словосполучення - «право на свободу мирних зібрань», яке лінгвістично розкриватиме зміст цього права, вказуватиме на його природу та гарантуватиме можливість здійснення кожним суб'єктом. ..., i, головне, обмежить суб'єктів владних повноважень від необгрунтованого втручання в здійснення права на свободу мирних зібрань, зокрема його обмеження чи заборони.

Ураховуючи сказане, вважаємо за доцільне ч. 1 ст. 39 Конституції України «Кожен має право на свободу мирних зібрань. Про здійснення даного права на вулищях, скверах, парках, інших громадських місцях, що перебувають у комунальній чи державній власності, завчасно сповіщаються органи виконавчої влади чи органи місцевого самоврядування». Зазначене цілком відповідатиме світовому досвіду формулювання права на свободу мирних зібрань, а також, по-перше, зсвідчуватиме приналежність даного права кожній людині, незалежно від ії правового статусу, і подруге, підкреслюватиме саме зміст цього права, відтіснивши форму здійснення права на свободу мирних зібрань на другий план, до того ж підтвердить природноправову складву цього права, позбавивши право на свободу мирних зібрань зайвої політизації. Відповідним чином вважаємо, ч. 1 ст. 315 ЦК України також має зазнати змін, і остання повинна містити норму такого змісту: «Фізичні особи мають право на свободу мирних зібрань, що передбачає вільно збиратися на мирні збори, конференщіi, засідання, фестивалі, проводити демнстрації, мітинги тощо. Зачасне сповіщення органів виконавчої влади або місцевого самоврядування про здійснення даного права здійснюється виключно в разі необхідності використання для здійснення даного права територій, приміщень, що перебувають у комунальній чи державній власності». Така єдність використання юридичних термінів на позначення одного й того ж явища - права на свободу мирних зібрань - у запропонованій термінологічній формулі сприятиме не лише соціальному призначенню та розумінню цього права всіма учасниками суспільних відносин, а й також гармонізує національне українське законодавство із європейським та міжнародним правовим досвідом регулювання права людини на свободу мирних зібрань.

\section{Використані джерела:}

1. Кіндюк Б. Особливості юридичної техніки Кодексу України про адміністративні правопорушення. Право України. 2019. № 10. С. 214-228.

2. Стефанчук Р. Юридична природа народовладдя як політико-правової категорії. Право Украӥни. 2019. № 10. С. 13-24. 
3.. Мамутов В. Повніше використовувати техніко-юридичні засоби удосконалення законодавства. Право Украӥни. 2008. № 2. С. 3-8.

4. Лебеденко В. І. Юридична техніка: поняття, призначення, методологічні засади застосування. Інформація і право. 2014. № 2 (11). С. 52-56.

5. Шутак I. Д. Дослідження актуальних та пріоритетних напрямків у галузі юридичної техніки. Journal «ScienceRise: Juridical Science». 2017. № 1(1). С. 32-36.

6. Пильгун Н. В., Смітюх А. С. Перспективи вдосконалення юридичної техніки в Україні. Юридичний Вісник. 2014. № 1 (30). С. 42-46.

7. Легка О. В. Юридична техніка законодавчих та правозастосовних актів. Науковий вісник Дніпропетровського державного університету внутрішніх справ. 2012. № 1. С. 101-107.

8. Панов М. І. Точність правових норм як необхідна умова якості правотворення. Юридична техніка: доктринальні основи та проблеми викладання: [тези доповідей та повідомлень учасників науково-практичної конференщії (м. Харків, 30 вересня - 1 жовтня 2015 року)] / за ред. проф. В. В. Комарова та І. Д. Шутака. Харків: Нац. юрид. ун-т ім. Ярослава Мудрого, 2015. С. 12-14.

9. Бесєдіна Л. Л. Термінологія та визначення понять в нормативно-правових актах. Інформація і право. 2012. № 2 (5). С. 39-47.

10. Самбор М. А. Форми здійснення права на свободу мирних зібрань. Вісник ХНУBC - Bulletin of KhNUIA. 2019. № 2 (85). C. 31-43.

11. Трихліб К. О. Гармонізація законодавства Украӥни і законодавства ЄС: наближення загальноправової термінології: автореф. дис... канд. юрид. наук за спец. 12.00 .01 теорія та історія держави і права; історія політичних і правових учень. Харків, 2014. 19 с.

12. Шкута О. Г. Репрезентація структурно-семантичних характеристик англомовних юридичних термінів українською мовою (на матеріалі офіційних текстів міжнародноправових документів. Вісник КНЛУ. Серія Філологія. Том 20. № 2. 2017. С. 147-155.

13. Самбор М. А. Право на свободу мирних зібрань в Україні: еволюція конституційних норм протягом століття. Вісник Луганського державного університету внутрішніх справ імені Е. О. Дідоренка. 2019. № 1 (85). С. 62-74.

14. Каленюк О. М. Розвиток української правничої термінології на західноукраїнських землях наприкінщі XIX - на початку XX століння: дис... канд. юрид. наук по спец. 12.00.01. теорія та історія держави і права; історія політичних і правових учень. К., 2015. 237 с.

15. Бахвалов С. В. Законодательная технология (некоторые проблемы теории и методологии): автореф. дис... канд. юрид. наук. по спец. 12.00 .01 - теория и история права и государства; история учений о праве и государстве. Нижний Новгород, 2006. 28 с.

16. Подорожна Т. С. Законотворчі помилки як чинник дестабілізації правового порядку. Юридична техніка: доктринальні основи та проблеми викладання: [тезидоповідей та повідомлень учасників науково-практичної конференщії (м. Харків, 30 вересня - 1 жовтня 2015 року)] / за ред. проф. В. В.Комарова та І. Д. Шутака. Харків: Нац. юрид. ун-т ім. Ярослава Мудрого, 2015. С. 53-56.

17. Кочан I. М. Юридична термінологія крізь призму лінгвістики. Науковий вісник гуманітраного університету. Сер.: Філологія. 2018. № 32. Том 3. С. 57-61.

18. Яцишин Н. П. Юридична термінологія як об'єкт мовознавчих досліджень. Науковий Вісник Волинського національного університету імені Лесі Украӥнки. 2011. № 6 (ч. 2). С. 219222. http:/ / esnuir.eenu.edu.ua/bitstream/123456789/2327/1/Yasyshyn.pdf (дата звернення: 10.01.2020).

\section{References:}

1. Kindyuk, B. (2019) Osoblyvosti yurydychnoi tekhniky Kodeksu Ukrainy pro administratyvni pravoporushennia. Pravo Ukrainy - Law of Ukraine, 10, 214-228. [in Ukrainian]. 
2. Stefanchuk, R. (2019) Yurydychna pryroda narodovladdia yak polityko-pravovoi katehorii. Pravo Ukrainy - Law of Ukraine, 10, 13-24. [in Ukrainian].

3. Mamutov, V. (2008) Povnishe vykorystovuvaty tekhniko-yurydychni zasoby udoskonalennia zakonodavstva. Pravo Ukrayiny - Law of Ukraine, 2, 3-8. [in Ukrainian].

4. Lebedenko, V. I. (2014) Yurydychna tekhnika: poniattia, pryznachennia, metodolohichni zasady zastosuvannia Informatsiia i pravo - Information and law, 2 (11), 52-56. [in Ukrainian].

5. Shutak, I. D. (2017) Doslidzhennya aktualnykh ta priorytetnykh napryamkiv u haluzi yurydychnoyi tekhniky Journal «ScienceRise: Juridical Science», 1 (1), 32-36. [in Ukrainian].

6. Pylhun, N. V., Smityukh, A. S. (2014) Perspektyvy vdoskonalennia yurydychnoi tekhniky v Ukraini. Yurydychnyi visnyk - Legal Bulletin, 1(30), 42-46. [in Ukrainian].

7. Lehka, O. V. (2012) Yurydychna tekhnika zakonodavchykh ta pravozastosovnykh aktiv Naukoryi visnyk Dnipropetrovskoho derzhavnoho universytetu vnutrishnikh sprav - Scientific Bulletin of Dnipropetrousk State University of Internal Affairs, 1, 101-107. [in Ukrainian].

8. Panov, M. I. (2015) Tochnist pravovykh norm yak neobkhidna umova yakosti pravotvorennia Yurydychna tekhnika: doktrynalni osnovy ta problemy vykladannia Kharkiv: Nats. yuryd. un-t im. Yaroslava Mudroho, 12-14. [in Ukrainian].

9. Besedina, L. L. (2012) Terminolohiia ta vyznachennia poniat v normatyvno-pravovykh aktakh. Informatsiya i pravo - Information and law, 2 (5), 39-47. [in Ukrainian].

10. Sambor, M. A. (2019) Formy zdiisnennia prava na svobodu myrnykh zibran. Visnyk KhNUVS - Bulletin of KhNUIA, 2 (85), 31-43. [in Ukrainian].

11. Trykhlib, K. O. (2014) Harmonizatsiia zakonodavstva Ukrainy i zakonodavstva YES: nablyzhennia zahalnopravovoi terminolohii. Extended abstract of Doctor's thesis. Kharkiv. [in Ukrainian].

12. Shkuta, O. H. (2017) Reprezentatsiia strukturno-semantychnykh kharakterystyk anhlomovnykh yurydychnykh terminiv ukrayinskoiu movoiu (na materiali ofitsiynykh tekstiv mizhnarodno-pravovykh dokumentiv. Visnyk KNLU. Seriya Filolohiya. - KNLU Bulletin. Philology Series. Vol. 20, 2, 147-155. [in Ukrainian].

13. Sambor, M. A. (2019) Pravo na svobodu myrnykh zibran v Ukrayini: evolyutsiya konstytutsiynykh norm protyahom stolittya. Visnyk Luhanskoho derzhavnoho universytetu vnutrishnikh sprav imeni E. O. Didorenka - Bulletin of Luhansk State University of Internal Affairs named after E. O. Didorenko, 1 (85), 62-74. [in Ukrainian].

14. Kalenyuk, O. M. (2015) Rozvytok ukrayinskoi pravnychoi terminolohii na zakhidnoukrayinskykh zemlyakh naprykintsi XIX - na pochatku XX stolinnya. Doctor's thesis. Kyiv. [in Ukrainian].

15. Bakhvalov, S. V. (2006) Zakonodatelnaya tekhnologiya (nekotoryye problemy teorii i metodologii). Extended abstract of Doctor's thesis. Nizhniy Novgorod. [in Russian].

16. Podorozhna, T. S. (2015) Zakonotvorchi pomylky yak chynnyk destabilizatsii pravovoho poryadku. Kharkiv: Nats. yuryd. un-t im. Yaroslava Mudroho. [in Ukrainian].

17. Kochan, I. M. (2018) Yurydychna terminolohiya kriz pryzmu linhvistyky. Naukoryi visnyk humanitranoho universytetu. Ser.: Filolohiia- Humanities University Bulletin. Ser.: Philology, 32, 57-61. [in Ukrainian].

18. Yatsyshyn, N.P. (2011) Yurydychna terminolohiia yak obyekt movoznavchykh doslidzhen. Naukooyi visnyk Volynskoho natsionalnoho universytetu imeni Lesi Ukrainky-Scientific-Bulletin of Volyn National University named after Lesya Ukrainka., № 6, 219-222. URL: http:// esnuir. eenu.edu.ua/bitstream/123456789/2327/1/Yasyshyn.pdf). [in Ukrainian]. 
Самбор H. А.,

кандидат юридических наук, начальник сектора мониторинга

Прилуцкого отдела полиции

Главного управления Национальной полиции

в Черниговской области

(г. Чернигов - г. Прилуки, Украина)

\section{ОСОБЕННОСТИ ЮРИДИЧЕСКОЙ ТЕРМИНОЛОГИИ В ФОРМУЛИРОВКЕ ПОНЯТИЯ ПРАВА НА СВОБОДУ МИРНЫХ СОБРАНИЙ}

В статье исследуются особенности использования юридической терминологии, призванной формулировать в содержании нормативно-правовых актов национального законодательства Украины понятие права на свободу мирных собраний. Анализ национального законодательства Украины позволил сделать вывод о том, что для обозначения права на свободу мирных собраний законодатель использует различные конструкции, а именно: «право на свободу мирных собраний», «право на мирные собрания», «право собираться мирно». Такая юридическая технология в использовании юридической техники для обозначения права человека не гарантирует единства его понимания и содержания. С учетом изложенного, предлагается внести изменения в действующее законодательство Украины и использовать единое понятие, которое наиболее полно, понятно и доступно раскроет содержание, цели и механизм (алгоритм) его осуществления данного права - «право на свободу мирных собраний».

Ключевые слова: право на свободу мирных собраний, право собираться мирно, право на мирные собрания, юридическая техника, юридическая терминология.

Sambor M., Ph. D. in Law,

Head of the monitoring Department of the Pryluky Police Department the Main Directorate of the National Police

in Chernihiv region (Chernihiv - Pryluky, Ukraine)

\section{FEATURES OF LEGAL TERMINOLOGY IN FORMULATING THE CONCEPT OF THE RIGHT TO FREEDOM OF PEACEFUL ASSEMBLY}

The article explores the peculiarities of the use of legal terminology intended to formulate in the content of normative legal acts of the national legislation of Ukraine the concept of the right to freedom of peaceful assembly. The analysis of the national legislation of Ukraine made it possible to conclude that in order to designate the right to freedom of peaceful assembly, the legislator uses different constructions, namely "right to freedom of peaceful assembly", "right to peaceful assembly", "right to assemble peacefully". Such legal technology in the use of legal technique for the designation of human rights does not guarantee the unity of its understanding and content, which the legal term entails.

They are convinced that the search for effective legal terms in the legal technique reflects the social needs and historical and legal representation of the society in the understanding of this 
law, its nature and peculiarities of implementation. The quality and uniqueness of the legal terms used in the legal acts used to refer to the right to freedom of peaceful assembly reflects the legislative strategy for the availability of the content of the legal acts for entities that will use these regulations to regulate the public relations of which participants these actors will speak. We are convinced that the use of different legal terms to refer to the same right to freedom of peaceful assembly separates the principle of comprehensibility of the rules of law for the subjects of its application and implementation, which affects the effectiveness of each subject's right to freedom of peaceful assembly.

In view of the above, it is proposed to amend the current legislation of Ukraine and use the only concept that will most fully, clearly and accessiblely reveal the content, purpose and mechanism (algorithm) of exercising this right - "right to freedom of peaceful assembly".

Keywords: right to freedom of peaceful assembly, right to assemble peacefully, right to peaceful assembly, legal technique, legal terminology. 